\title{
Double Crush Syndrome of the Median Nerve: A Literature Review
}

\section{Síndrome do duplo impacto do nervo mediano: uma revisão de literatura}

\author{
Marcelo José da Silva Magalhães 1,2,3,4 Alice Augusto Costa Correia ${ }^{1}$ \\ Emannuelly Aparecida Silva da Cruz ${ }^{1}$ Fernanda Caldeira Veloso Santos ${ }^{1}$ José Antônio de Aguiar Filho ${ }^{1}$ \\ Lorena Aparecidade Lourdes $^{1}$ Luísa Malheiro Ferreira ${ }^{1}$ Synara Figueiredo Silva de Quadros ${ }^{1}$ \\ ${ }^{1}$ Department of Medicine, Faculdades Unidas do Norte de Minas, \\ Address for correspondence Marcelo José da Silva de Magalhães, MD, \\ Montes Claros, MG, Brazil \\ 2 Department of Medicine, Faculdades Integradas Pitágoras de \\ MSc, Rua Francisco Versiane Athaide, 760, Cândida Câmara, Montes Claros, \\ MG, Brazil. CEP: 39401-039 (e-mail: marcelo7779@yahoo.com.br). \\ Montes Claros, Montes Claros, MG, Brazil \\ ${ }^{3}$ Department of Neurosurgery, Hospital Aroldo Tourinho, Montes \\ Claros, MG, Brazil \\ ${ }^{4}$ Department of Neurosurgery, Hospital Vila da Serra-Nova, Lima, MG, Brazil \\ Arq Bras Neurocir 2019;38:36-39.
}

\begin{abstract}
Keywords

- double crush syndrome

- median nerve

- carpal tunnel

- neuropathy

Resumo

Double crush syndrome (DCS) is defined as the compressive involvement of the same peripheral nerve in different segments. When this syndrome affects the median nerve, a proximal compression of a spinal nerve that will constitute this structure (often the spinal nerve at the C6 vertebra) is usually noted at the cervical spine level as a herniated disc and as a distal compression at the level of the carpal tunnel. Epidemiological data on median nerve compromise by DCS are still very scarce in the medical literature. The diagnosis can be inferred by symptoms and signs occurring proximally and distally in the arm, as well as by alterations revealed by upper limb electromyography and neuroimaging studies, such as magnetic resonance imaging (MRI) of the cervical spine. Nowadays, information on which compressed neuroanatomical point should be initially addressed still depends on further studies. Limited data infer that these patients, when submitted to surgical treatment in only one of the median nerve compression points, evolve with worse functional outcomes than the surgically-treated group with carpal tunnel syndrome without DCS.

A síndrome do duplo impacto (SDI) é conceituada como o comprometimento compressivo de um mesmo nervo periférico em segmentos distintos. Quando esta síndrome acomete o nervo mediano, usualmente se nota uma compressão proximal de um nervo espinhal que irá constituir o nervo mediano (frequentemente, o nervo espinhal da vértebra (6) ao nível da coluna cervical por uma hérnia discal e uma compressão distal ao nível do túnel do carpo. Dados epidemiológicos sobre a SDI comprometendo o nervo mediano ainda são muito escassos na literatura médica.
\end{abstract}

received

May 29, 2016

accepted

August 30, 2016
DOI https://doi.org/

$10.1055 / \mathrm{s}-0036-1594261$.

ISSN 0103-5355.
Copyright $\odot 2019$ by Thieme Revinter

Publicações Ltda, Rio de Janeiro, Brazil

License terms

c) $(1) \$$ 
Palavras-chave

- síndrome do duplo impacto

- nervo mediano

- túnel do carpo

- neuropatia
Observa-se que o diagnóstico pode ser inferido por sintomas e por sinais presentes proximal e distalmente no membro superior, além de alterações presentes na eletroneuromiografia de membros superiores, bem como achados em exames de neuroimagem como a ressonância magnética da coluna cervical. Atualmente, a informação sobre qual ponto neuroanatômico de compressão deveria ser abordado inicialmente ainda depende de mais estudos. Dados escassos inferem que esses pacientes, quando submetidos ao tratamento cirúrgico em apenas um dos pontos de compressão do nervo mediano, evoluem com resultados funcionais piores do que o grupo de pacientes com síndrome do túnel do carpo sem SDI tratados cirurgicamente.

\section{Introduction}

Double crush syndrome (DCS) refers to the coexistence of a double compression along the course of the same peripheral nerve. ${ }^{1,2}$ A hypothesis proposed in 1973 by Upton et al describes the potential susceptibility of a distal nerve segment to lesion after a proximal injury. ${ }^{1,3}$ It also emphasizes that the damage produced by double compression exceeds the additive injury caused by each compression, harming the global functioning of the nerve cells. 4,5

This hypothesis can explain why patients with carpal tunnel syndrome (CTS) sometimes feel pain in the forearm, in the elbow, in the arm, in the shoulder, in the chest, and in the upper back region. ${ }^{1,6}$ The DCS also can explain some cases of surgical failure, when the isolated CTS treatment did not result in pain control. ${ }^{1,6}$ The DCS manifests as a disorder including pain, numbness and weakness due to two or more insults to the same peripheral nerve., ${ }^{3,7}$ When it involves the median nerve, the coexistence of CTS and of cervical radiculopathy is the most frequent DCS pattern. ${ }^{2,4}$

CTS affects $\sim$ between 3 and $4 \%$ of the general population, with a prevalence of female patients in a 5:1 ratio, and in ages ranging from 30 to 60 years old. ${ }^{8-10}$ The incidence of cervical radiculopathy appears to be in $<1 \%$ of the population, often with a peak at the ages between 50 and 54 years old. ${ }^{11-13}$

In view of these issues, the present study aims to describe the epidemiological aspects, the risk factors, and the histopathological mechanisms involved in the DCS.

\section{Methodology}

The present study is a bibliographic review based on the specialized literature, and it was performed through the consultation of selected scientific papers at the PubMed database. To prepare the present work, the search used the descriptors double crush syndrome and median nerve. Only papers with patients presenting median nerve compression were included. Papers on distal compression of the median nerve with no CTS involvement were excluded.

\section{Discussion}

Carpal tunnel syndrome is the most frequent compressive syndrome, and it is defined by the compression of the median nerve at the level of the wrist. Its first description is assigned to Paget, who reported a case of medial nerve compression as a result of a distal radius fracture. ${ }^{14}$

The carpal tunnel is an inextensible osteofibrous tunnel defined as the space between the flexor retinaculum (FR), which constitutes its roof, and the carpal channel, which constitutes its fundus. It is delimited at the ulnar border by the hook of the hamate bone, the pyramidal bone and the pisiform bone, and at the radial border by the scaphoid bone, the trapezoid bone, and the FR. Its base is formed by the capsule, and the anterior radiocarpal ligaments cover the underlying portions of the scaphoid, semilunar, capitate, hamate, trapezium and trapezoid bones. ${ }^{15}$ The median nerve is followed by four tendons of the digital flexor superficial muscles (FSD), four tendons of the digital deep flexor muscles (FPD), and by the tendon of the long flexor muscle of the thumb (FLP). ${ }^{15}$ The FLP is the most radial element. At the entrance of the tunnel, the median nerve is dorsal to the tendon of the palmaris longus (PL) muscle, between the carpal radial flexor tendon (FCR) and of the digital superficial flexor tendon (SDFT). ${ }^{15}$ At the distal part of the tunnel, the median nerve is divided in lateral, medial and thenar recurrent branches; the former two branches subdivide further. ${ }^{15}$ The thenar branch passes through a separate tunnel before entering the thenar muscles in $56 \%$ of the cases. ${ }^{15}$

Typical CTS symptomatology is manifested by pain, hypoesthesia and paresthesia in the sensory innervation territory of the median nerve and, in some cases, by paresis for thumb opponency and abduction, as well as by signs of thenar hypotrophy. ${ }^{2}$

The differential diagnosis should include C6 and C7 vertebrae radiculopathy, proximal medial nerve compressions in the arm (Struthers ligament) or in the forearm (pronator syndrome), and double impact syndrome. Less frequently, upper motor neuron disease, cervical intraradicular injuries, neuropathies, and syringomyelia can be considered in the differential diagnosis. ${ }^{2}$

As already discussed, DCS is postulated as the compressive involvement of more than one point of the same peripheral nerve. In median nerve DCS, this can be exemplified by the compression of a spinal nerve-which will contribute to the formation of the median nerve at the brachial plexus leveland by the presence of an injury at a distal point of the same nerve, especially in the carpal tunnel. ${ }^{1}$ 
The prevalence of DCS in CTS patients, cumulated with cervical radiculopathy, varies greatly in the medical literature. Some studies report a $5 \%$ prevalence, while others state that $94 \%$ of the studied patients are affected. ${ }^{16-18}$ This extensive variation could be partially explained by the lack of a gold standard for the diagnosis of DCS. ${ }^{16-18}$ Some aspects, however, can be pointed out, such as the higher prevalence in males, according to studies by Tian et al. ${ }^{19}$

Different physiopathological mechanisms for DCS were suggested, and can be divided into highly plausible (1-4) and plausible.

(1) Axonal transport: Animal studies revealed that axonal transport is compromised by the mechanical pressure on the nerve at levels commonly observed in humans. ${ }^{16}$

(2) Super-regulation and under-regulation of ion channels: The super-regulation of sodium channels and the underregulation of potassium channels are observed at points adjacent to the nerve compression site and could lead to a reduction in the neuronal action potential threshold. ${ }^{16}$

(3) Inflammatory process in the spinal nerve sensory ganglion: The mechanical compression process of the spinal nerve would lead to the invasion of its sensory ganglion by immune cells. This process would trigger the release of cytokines that would lower the threshold to initiate action potentials in sensory neurons located at the sensory ganglion. ${ }^{16}$

(4) Neuromas-in-continuity: Mechanical lesions on a peripheral nerve with an intact epineurium could lead to a defective regeneration of axon fibers in such a way that, during this process, they could not reach the peripheral target, forming neuromas along the nerve trunk. ${ }^{16}$

(5) Central sensitization: The nerve compression process would lead to central sensitization, promoting membrane excitability changes that would reduce inhibition, causing a reduction in the pain thresholds. ${ }^{16}$

(6) Nerve biomechanical aspects and movement patterns: During the movement of the limbs, the nerve slides over the adjacent tissue in longitudinal and transverse directions. Disturbances, such as a mechanical compression, could increase distal tension, compromising the biomechanics of the nerve. ${ }^{16}$

(7) Cognitive, psychological and psychosocial factors: Fear or hypervigilance states would reduce pain thresholds in these patients. ${ }^{16}$

(8) Peripheral nerve and spinal cord immunoinflammation: Immunoinflammatory processes at different points of the nervous system could reduce the action potentials thresholds of sensory neurons. ${ }^{16}$

(9) Microcirculation damage: The nerve compression would affect the microcirculation of the nerve, resulting in intraneural and extraneural edema. ${ }^{16}$

(10) Combined mechanisms: This theory tries to explain DCS through a sum of the aforementioned mechanisms. ${ }^{16}$

The risk factors for DCS include conditions that predispose patients to CTS and cervical disc herniation. The risk factors for CTS include diabetes mellitus, alcohol abuse, amyloidosis, rheumatoid arthritis, infectious synovitis, gout, dermatomy- ositis, scleroderma, hypothyroidism, long-term hemodialysis, obesity, repeated wrist flexion-extension movements, extended wrist during loaded movements, and fist injuries. ${ }^{20}$ The risk factors for cervical disc herniation include smoking, cumulative effect of spine microtraumas and macrotraumas, and osteoporosis. ${ }^{21}$ It is noteworthy that some studies point to the male gender and increased age as independent risk factors for DCS. ${ }^{22}$

The specific symptomatology observed in DCS patients are CTS symptoms plus pain and cervical region, shoulder and upper limb hypoesthesia ipsilateral to the nerve compression. ${ }^{23}$

The electromyographic changes observed in DCS are more pronounced than those present in CTS alone. A study comparing electroneuromyography (ENM) findings in patients with only CTS or DCS (CTS plus cervical radiculopathy) shows that the latter present lower sensory and motor nerve conduction velocity and higher distal motor latency. Importantly, these ENM differences were statistically significant. ${ }^{23}$

Although there are specific diagnostic criteria for CTS, they are yet to be established for DCS. ${ }^{13,24}$ The diagnosis of cervical radiculopathy is determined by the clinical history of the patient and imaging tests, such as cervical X-rays, which can show cervical osteophytosis, as well as computed tomography (CT) and magnetic resonance imaging (MRI) exams. ${ }^{25,26}$ For some authors, the history of the patients, signs such as Phalen or Tinel-Hoffmann, and the presence of thenar hypotrophy can be very relevant. ${ }^{27,28}$ These clinical tests serve as screening tools for an electroneuromyographic study, which is considered the gold standard for the diagnosis of CTS. ${ }^{23,28}$

Regarding the most appropriate surgical treatment for DCS patients, some inferences can be suggested from studies with CTS patients with unsatisfactory postprocedural pain control. $^{4,29}$ The isolated surgical treatment of the distal compression did not provide pain control if there was a proximal compression of the median nerve. Eason described 47 CTS surgeries with unsatisfactory outcomes for pain control. ${ }^{4,29}$ In 38 of these procedures, it was possible to identify an intervertebral foramen stenosis at the cervical level. ${ }^{4,29}$

Two remaining issues would be the best course for DCS patients, and which nerve compression point should be initially approached in surgery. Baba et al reviewed the medical records of 483 patients, from which 65 showed peripheral and cervical signs and symptoms, being classified as DCS carriers. $^{23,25}$ These authors suggest that the decompression of the cervical spinal nerve should be initially performed to reduce myelopathy risks due to cervical disc herniation. ${ }^{23}$ As such, later, the patient would be submitted to CTS treatment. ${ }^{23}$

\section{Conclusion}

Although DCS is recognized as a distinct clinical entity, the exact operation of its neurophysiological and cellular mechanisms is not yet sufficiently known and universally accepted. Some patients with CTS can be DCS carriers. There is no consensus regarding the median nerve site that should be initially decompressed. Further studies are required in order to better document the physiopathology and the most efficient treatment for this condition. 


\section{References}

1 Upton AR, McComas AJ. The double crush in nerve entrapment syndromes. Lancet 1973;2(7825):359-362

2 Huang YG, Chang SM. Double crush syndrome due to plating of humeral shaft fracture. Indian J Orthop 2014;48(02):223-225

3 Vincifora C, Buck T. Two cases of Double Crush Syndrome Progressing to Complex Regional Pain Syndrome. Journal of Anesthesiology 2015;5:183-186

4 Osterman AL. The double crush syndrome. Orthop Clin North Am 1988;19(01):147-155

5 Waxman SG. Aging, degeneration, regeneration, and plasticity. In Correlative Neuroanantomy 24th edition. New York: Lange/ McGrawHill; 2000:282

6 Russell BS. Carpal tunnel syndrome and the "double crush" hypothesis: a review and implications for chiropractic. Chiropr Osteopat 2008;16:2

7 Zahir KS, Zahir FS, Thomas JG, Dudrick SJ. The double-crush phenomenon-an unusual presentation and literature review. Conn Med 1999;63(09):535-538

8 Papanicolaou GD, McCabe SJ, Firrell J. The prevalence and characteristics of nerve compression symptoms in the general population. J Hand Surg Am 2001;26(03):460-466

9 Atroshi I, Gummesson C, Johnsson R, Ornstein E, Ranstam J, Rosén I. Prevalence of carpal tunnel syndrome in a general population. JAMA 1999;282(02):153-158

10 Spinner RJ, Bachman JW, Amadio PC. The many faces of carpal tunnel syndrome. Mayo Clin Proc 1989;64(07):829-836

11 Carette S, Fehlings MG. Clinical practice. Cervical radiculopathy. N Engl J Med 2005;353(04):392-399

12 Radhakrishnan K, Litchy WJ, O'Fallon WM, Kurland LT. Epidemiology of cervical radiculopathy. A population-based study from Rochester, Minnesota, 1976 through 1990. Brain 1994;117(Pt 2):325-335

13 Salemi G, Savettieri G, Meneghini F, et al. Prevalence of cervical spondylotic radiculopathy: a door-to-door survey in a Sicilian municipality. Acta Neurol Scand 1996;93(2-3):184-188

14 Paget J. The first description of carpal tunnel syndrome. J Hand Surg Eur Vol 2007;32(02):195-197

15 de Krom MC, Knipschild PG, Kester AD, Thijs CT, Boekkooi PF, Spaans F. Carpal tunnel syndrome: prevalence in the general population. J Clin Epidemiol 1992;45(04):373-376

16 Schmid AB, Coppieters MW. The double crush syndrome revisited-a Delphi study to reveal current expert views on mechan- isms underlying dual nerve disorders. Man Ther 2011;16(06): 557-562

17 Morgan G, Wilbourn AJ. Cervical radiculopathy and coexisting distal entrapment neuropathies: double-crush syndromes? Neurology 1998;50(01):78-83

18 Golovchinsky V. Relationship between damage of cervical nerve roots or brachial plexus and development of peripheral entrapment syndromes in upper extremities (double crush syndrome). J Neurol Orthop Med Surg 1995;16:61-69

19 Tian MT, Bai L, Shao SY, Wang TB, Jiang BG. [Analysis of clinical outcomes of carpal tunnel syndrome combined with cervical nerve root compression]. Beijing Da Xue Xue Bao Yi Xue Ban 2012;44(06):838-841

20 Flores LP. Compressão do nervo mediano no punho (Síndrome do túnel do carpo). In: Siqueira MG, Martins R. Síndromes Compressiva de Nervos Periféricos. Rio de Janeiro: Di Livros Editora; 2008

21 Mark Greenberg. Handbook of neurosurgery. 7th edition. 2010

22 Moghtaderi A, Izadi S. Double crush syndrome: an analysis of age, gender and body mass index. Clin Neurol Neurosurg 2008;110 (01):25-29

23 Baba H, Maezawa Y, Uchida K, et al. Cervical myeloradiculopathy with entrapment neuropathy: a study based on the double-crush concept. Spinal Cord 1998;36(06):399-404

24 Wang R, Liu Z, Wang W, et al. [Carpal tunnel syndrome with cervical spondylotic radiculopathy: a clinical and electrophysiological study]. Zhonghua Yi Xue Za Zhi 2015;95(35):2846-2850

25 Hurst LC, Weissberg D, Carroll RE. The relationship of the double crush to carpal tunnel syndrome (an analysis of 1,000 cases of carpal tunnel syndrome). J Hand Surg [Br] 1985;10(02):202-204

26 Sociedade Brasileira de Ortopedia e Traumatologia, Sociedade Brasileira de Neurocirurgia e Sociedade Brasileira de Neurofisiologia Clínica. Síndrome doTúnel do Carpo: Tratamento. Diretrizes Clínicas na Saúde Suplementar, 2011

27 Turrini E, Rosenfeld A. Diagnóstico por Imagem do Punho na Síndrome do Túnel do Carpo. Departamento de Diagnóstico por Imagem da Universidade Federal de São Paulo, São Paulo, SP, Brasil, 2005

28 Kuhlman KA, Hennessey WJ. Sensitivity and specificity of carpal tunnel syndrome signs. Am J Phys Med Rehabil 1997;76(06):451-457

29 Eason SY, Belsole RJ, Greene TL. Carpal tunnel release: analysis of suboptimal results. J Hand Surg [Br] 1985;10(03):365-369 